\title{
Educational Aspects in Efforts to Realize SDGs in Indonesia
}

\author{
Husni Thamrin*
}

Awang Long School of Law, Samarinda, Indonesia

DOI: $\underline{10.36348 / j a e p .2020 . v 04 i 11.007}$

| Received: 05.11.2020 | Accepted: 16.11.2020 | Published: 19.11.2020

*Corresponding author: Husni Thamrin

\section{Abstract}

This paper aims to analyze Indonesia's readiness in realizing SDGs 2030 in the field of education and the things that hinder the implementation of SDGs 2030 in the education sector in Indonesia. This type of research is normative by using a statutory approach and a conceptual approach. The data used is secondary data obtained through library research. All data collected were then analyzed qualitatively. The results show that Indonesia's readiness in realizing SDGs 2030 in the education sector is due to a commitment to play a strong role in achieving SDGs in three main ways, namely policy advocacy and consultation, capacity building and knowledge sharing. In terms of access to education, UNESCO can provide significant assistance to the Government of Indonesia, particularly in areas related to the promotion of quality education for all; improving the quality of education at the basic education level; and literacy quality for all. In addition, UNICEF also has a focus area in terms of Basic Education for All, which can make a useful contribution to the Government of Indonesia. The main thing that hinders the implementation of SDGs 2030 in the education sector in Indonesia is related to the quality of education as well as the quality of teachers which is still lacking.

Keywords: Education, Indonesia, SDGs.

Copyright ( 92020 The Author(s): This is an open-access article distributed under the terms of the Creative Commons Attribution 4.0 International License (CC BY-NC 4.0) which permits unrestricted use, distribution, and reproduction in any medium for non-commercial use provided the original author and source are credited.

\section{INTRODUCTION}

Education is very important for a country, education can be an indicator in the assessment given by other countries to a country, whether the country is categorized as a developed country, a developing country, or an underdeveloped country. Of course the assessment can be from all aspects and many determining factors, but the aspect of education is one of the main aspects that becomes an assessment. Without good education, a country will certainly experience difficulties in carrying out development, adaptation to increasingly advanced technology, and the worst thing is the increasing poverty rate in the country because the mindset that should be able to develop because of education, this does not materialize. Advanced education can also have a very positive impact on the country, both in terms of human resources and from an economic perspective.

The disruption of the learning process in Indonesia as a result of the response to the Covid-19 pandemic has the potential to disrupt the agenda for achieving SDG-4 (Quality education for all). The disruption occurs in two aspects: First, the overall quality of learning is reduced, due to sudden disruption in the learning process without adequate infrastructure prerequisites and resources. Second, the increase in inequality in educational attainment due to this disruption will be felt more severely by the poor or in remote areas. These two aspects, equality of access and quality of achievement are the most urgent homework of achieving SDG-4 in Indonesia. The policies of almost all countries in the world to carry out a lockdown, or Large-Scale Social Restrictions (PSBB) in Indonesia, in a pandemic condition, have an impact on student and student learning interruptions, including the teaching and learning process and the learning evaluation process. UNESCO, for example, reports that around 177 countries in the world have closed schools so that more than 1.2 million students are also affected. In Indonesia this policy affects approximately 68 million children and adolescents, namely about 5 million preschool children; 24.7 million elementary school (SD) children; 9.9 million children and adolescents in Junior High School (SMP); 9.9 million teenagers from Senior High School and Vocational High School (SMA \& SMK); and 8 million students[1]. Online learning schemes are considered to be the best response to mitigate this disruption. However, its effectiveness is greatly influenced by our experience in the online learning management process and the availability of infrastructure access for all students and students. Without these two prerequisites, the 
effectiveness of learning will be disrupted and the achievement of the SDGs targets in education will be more difficult to achieve [2]. This needs to be the government's main concern, considering that the SDGs have been running for 5 years, and their implementation is currently being disrupted by a pandemic that was not planned beforehand.

SDGs are a cluster of soft law international agreements [3]. Indonesia as a major subject in international law [4] also have an interest to comply with and follow this international agreement. Education today is a fundamental right in the value of human life. Education has a very important role to support human life because basically humans in carrying out their lives cannot be separated from education. The implementation and development of educational studies must also be adapted to the social conditions and situations in society. Because education is like an experiment that is never finished at any time, as long as there is human life in this world. It is said so because education is a part of human culture and civilization that continues to develop. This is in line with human nature who has creative and innovative potential. Education does not only play a role in creating the younger generation as agents of change that bring change, but the younger generation must be able to become agents of producers who are able to create real change. Education must be able to become a patron, not only in terms of formal education, but what is meant is education that is able to change the mindset of the nation's children and innovative education that encourages creativity and innovative power of the nation's children. The younger generation as agents of innovation who can make an important and significant contribution to applying applicable sustainable development concepts [5]. The concepts of sustainable development are what every country wants to realize in achieving the highest degree of progress.

The progress of a country lies in the quality of its human resources, and education has an important role in building quality resources, as well as capital to create a sustainable future, good quality education is certainly necessary to create a competitive productive Indonesian society, and also able to compete in the arena. world. The SDGS program, in an effort to build Quality education, has formulated 10 designed goals, one of which is to ensure that all students will acquire the knowledge and skills desired to promote sustainable development, besides that this program will also increase the supply of quality teachers, for the sake of achieving education development. According to Masrufah Ihsan, this SDGS program is extraordinary, and sincerely hopes that the government and the community can work together in realizing SDGS 2030, especially in the field of education, because with the success of an education it will also bring success in other development goals, because it can realize other developments, we need a quality, and we can absorb this quality through education. To realize this educational goal, Indonesia is not only silent, there are many things that the government has done, such as providing school operational assistance which has been implemented since 2005 when President Jokowi's nawacita is related to education with tangible results, namely the existence of a smart Indonesian card [6]. Thus, it is seen from this fact that there have actually been extra efforts that have been made by the government in realizing SDGs in the field of education.

The right to education has been recognized as part of human rights universally for decades, particularly since the adoption of the Universal Declaration of Human Rights, which sets the foundation for the idea that education, as part of human rights, should be provided free of charge, especially at the primary level, and that education must be equally accessible to everyone based on quality/achievement. 1 Then, the international legal framework on the right to education is further expanded in various international treaties adopted after the UDHR, namely, the International Covenant on Economic, Social and Cultural Rights Articles 13 and 14; Convention on the Rights of the Child, Articles 28 and 29; and Convention on the Rights of Persons with Disabilities, Article 24. The Committee for Economic, Social and Cultural Rights outlines some of the main elements that must be present in the provision of education, namely the elements of availability, accessibility, acceptability, and can be adapted. These four elements really need to be considered by governments that are States parties to the Covenant on Economic, Social and Cultural Rights when implementing the fulfillment of the right to education in their respective countries. Indonesia has been a State Party to the Covenant on Social, Social and Cultural Rights since 2005, therefore, Indonesia is bound by the obligations stipulated in the Covenant, including the obligations to respect, protect and fulfill the rights of every Indonesian citizen to education. In addition, the right to education is guaranteed in the 1945 Constitution, particularly in Article 31, which not only recognizes that education is a right, but also stipulates an obligation for the State to allocate a budget of at least $20 \%$ of the APBN for the provision of education for all. This is related to [7]:

\section{Availability}

A sufficient number of well-functioning educational institutions and programs shall be provided within the jurisdiction of the State Party. What these institutions need to function depends on several factors, including the development context in which they operate; for example, all educational institutions and programs may need buildings or protection of various elements, sanitation facilities for both sexes, safe drinking water, teachers who are trained and receive competitive salaries domestically, teaching materials, etc. ; meanwhile, other educational institutions also 
need facilities such as libraries, computers and information technology.

\section{Accessibility}

Accessibility has three interrelated dimensions:

- Non-discrimination: Education must be accessible to all people, especially by the most vulnerable groups, both legally and in fact, without discrimination on any prohibited basis;

- Physical accessibility: Education must be safe to reach physically, either in terms of attendance in geographically convenient locations (for example, a school environment) or through modern technology (for example, access to a "learn from afar" program. );

- Economic accessibility: Education must be affordable for all. This one dimension of accessibility depends on the use of a different sentence in Article 13 (2), in relation to primary, secondary and tertiary education: that primary education should be provided "free of charge to all", States Parties are obliged to progressively initiated the provision of free education at secondary and tertiary levels.

\section{Acceptability}

The form and substance of education, including curriculum and teaching methods, must be acceptable (eg, relevant, culturally acceptable and of good quality) for students and, in some cases, by parents.

\section{Can be adapted (adaptability)}

Education must be flexible so that it can adapt to the needs of changing societies and communities and can respond to the needs of students with diverse social and cultural backgrounds.

Based on this explanation, the problem that will be discussed in this paper is how is Indonesia's readiness in realizing SDGs 2030 in education? and what matters hinder the implementation of SDGs 2030 in the education sector in Indonesia?

\section{RESEARCH METHOD}

This type of research is normative [8] by using a statutory approach and a conceptual approach [9]. The data used is secondary data obtained through library research [10]. All data collected were then analyzed qualitatively.

\section{RESULTS AND DISCUSSION Indonesia's Readiness in Realizing SDGs 2030 in the Education Sector}

As stated earlier that the right to get an adequate quality of education is one of the human rights possessed by every human being wherever he is [11]. Internationally, the quality of education in Indonesia is ranked 64th out of 120 countries worldwide based on the 2012 UNESCO Education For All Global
Monitoring Report. Meanwhile, based on the Education for All Development Index (EDI), Indonesia is at ranked 57th out of 115 countries in 2015 . In the latest 2015 UN development program report, Indonesia ranks 110 out of 187 countries in the Human Development Index (HDI) with a figure of 0.684. With this figure, Indonesia still lags behind the two ASEAN neighbors, namely Malaysia (62) and Singapore (11). Based on the above, the goals of education will also become the foundation of government efforts to encourage the achievement of the goals and targets of sustainable development in the era of Sustainable Development Goals (SDGs) until 2030 based on the direction of the United Nations Forum which was agreed on 2 August 2015. Improving education for the Indonesian people spur the achievement of other goals and targets in the 17 SDGs points, especially to increase Indonesia's human development index. So it is hoped that the role of education will be able to increase Indonesia's competitiveness in supporting SDGs 2030 [12]. The 4th goal of the SDGs in Education is to ensure inclusive and equal quality education, while also supporting lifelong learning opportunities for all. Therefore, the target of the 4 SDGs is [13]:

1. By 2030, ensure that all girls and boys complete free, equal and quality primary and secondary education, leading to relevant and effective learning outcomes

2. By 2030, ensure that all girls and boys have access to quality early childhood development as well as care and pre-primary education so that they are ready for primary education

3. By 2030, ensure equal access for all women and men to quality and affordable higher education, technical and vocational education, including university

4. By 2030, substantially increase the number of youth and adults who have relevant skills, including technical and vocational skills, to find decent work and self-employment

5. By 2030, eliminate gender disparities in education and ensure equal access to all levels of education and vocational training for those who are vulnerable, including those with disabilities, indigenous peoples and children in vulnerable situations

6. By 2030, ensure that all adolescents and some adults, both boys and girls, achieve literacy and numeracy

7. By 2030, ensure that those who learn acquire the knowledge and skills needed to support sustainable development, including, inter alia, through education for sustainable development and sustainable lifestyles, human rights, gender equality, promoting a culture of peace and nonviolence, global population and an appreciation of cultural diversity and the contribution of culture to sustainable development

- Build and upgrade education facilities that are sensitive to gender, children and disabilities and 
provide safe, nonviolent, inclusive and effective learning environments for all

- By 2020, substantially increase the number of scholarships available to developing countries, in particular least developed countries, small island developing States and African countries, for entry into higher education, including vocational training and information and communication technology, engineering, engineering and science programs, in developed and other developing countries

- By 2030, substantially increase the supply of qualified teachers, including through international cooperation for teacher training in developing countries, in particular least developed countries and small island developing States.

Various UN agencies and programs in Indonesia are committed to playing a strong role in assisting the Government of Indonesia to achieve the SDGs in three main ways, namely policy advocacy and consultation, capacity building and knowledge sharing. In terms of access to education, UNESCO can provide significant assistance to the Government of Indonesia, particularly in areas related to the promotion of quality education for all; improving the quality of education at the basic education level; and literacy quality for all. In addition, UNICEF also has a focus area in terms of Basic Education for All, which can make a useful contribution to the Government of Indonesia, particularly in relation to improving the skills of school principals, supervisors and officials in the education sector to manage and deliver quality basic education for all child; and engage local civil society organizations and communities to provide better services for marginalized children, for example, through improved school-based management [14]. Thus, these factors can accelerate the implementation of SDGs in education in Indonesia.

\section{Inhibiting Factors for the Implementation of SDGs 2030 in the Education Sector in Indonesia}

Judging from the world of education in Indonesia, there are still many obstacles especially those related to the quality of education such as the quality of teachers which is still lacking, in fact this is the most important, various financial assistance provided by the government is not the only way to build the quality of education. but Indonesia also needs to prepare teachers who are competent in guiding students, in order to build quality human resources, because if we talk about education it will not be separated from the discussion of schools that function as educational institutions, as well as if we talk about education and schools so do not put aside the problems of teaching and organization in schools. So what needs to be improved in education is not only the programs and goals of the government, but teaching and social life in schools are also needed, because this is the point of activity of education itself, in order to realize the goals of education, cooperation is also needed between schools such as teachers, school principals and parents and other stakeholders, all parties need to manage students to the maximum extent possible so that goals are achieved through various lessons presented by the teacher. To maximize the school program, two main things are needed, namely the organization and administration of counseling services and guidance programs. Organization is a means of cooperation between personnel to achieve common goals, while administration is an activity to regulate work traffic so that these activities remain smooth, efficient and effective. If the school program has been fulfilled, then the convenience of students in learning is likely to be successful, when a learning has been successful, the quality of a person will increase from day to day, therefore it is important in order to build sustainable education both formulated in SDGS 2030 goals or educational goals through nawacita government, not only in terms of financial, but the school itself has quality in serving students. For this reason, it is hoped that every party who comes into contact with schools and education is important for your contribution in advancing the nation's education through teaching and implementing educational programs in schools properly [15]. Although the legal framework and budgeting commitments in Indonesia are deemed adequate for the fulfillment of access to adequate education for all citizens, Indonesia is still teetering in the face of challenges that hinder the enjoyment of the right to quality education for everyone. These challenges are, among others, as follows [16]:

- High literacy rate, amounting to $93.88 \%$, but more than $50 \%$ of Indonesians aged 15 years do not have basic reading or math skills (OECD);

- Primary school teachers in rural/remote areas are less qualified and often absent from school (OECD);

- There are $75 \%$ of primary schools that fail to meet minimum service standards such as the proportion of student-teachers and inadequate school facilities;

- The net participation rate of basic education is 96.70\%; junior high school $77.82 \%$; and senior high school $59.71 \%$. (BPS);

- The participation rate for higher education is: $17.34 \%$ (BPS);

- The allocation of funding for early childhood development and education remains relatively low at the level of $1.2 \%$ of the education budget, while the international threshold is $4-5 \%$; most of the growth and participation in early childhood care and education comes from the private sector and is only accessible to capable parents.

- Despite progressive efforts to ratify the CRPD and education frameworks that promote inclusive education, the participation rates of children with disabilities remain low, at $0.25 \%$ and $0.13 \%$ of students participating in primary and junior secondary schools, with the participation of boys men are taller than girls. (OECD). 
- The availability of special schools varies greatly between provinces, from 457 schools in East Java to only 4 in West Papua. The majority of provinces outside Java have fewer than 10 special schools. (OECD);

- Indigenous children are deprived of education due to lack of economic, geographic and cultural access. The majority of indigenous peoples live far from general administrative geographic areas, especially in or around forests and are very remote, where very few schools are within reach. Many indigenous families cannot afford to send their children to school, while some indigenous groups also still live nomadically, making it more difficult to maintain children's school attendance.

Although some of the above challenges have been included in order to be able to be overcome in the national development agenda, there are still some things that still need to be considered so that they are included in the agenda, so that it can be ensured that all the main elements in the implementation of the right to education can be fulfilled [17]. A number of these inhibiting factors need to be addressed by the government by means of synergy between the central government and local governments in advancing the quality of education in Indonesia.

\section{CONCLUSION}

Indonesia's readiness in realizing SDGs 2030 in the education sector is due to a commitment to play a strong role in achieving SDGs in three main ways, namely policy advocacy and consultation, capacity building and knowledge sharing. In terms of access to education, UNESCO can provide significant assistance to the Government of Indonesia, particularly in areas related to the promotion of quality education for all; improving the quality of education at the basic education level; and literacy quality for all. In addition, UNICEF also has a focus area in terms of Basic Education for All, which can make a useful contribution to the Government of Indonesia. The main thing that hinders the implementation of SDGs 2030 in the education sector in Indonesia is related to the quality of education as well as the quality of teachers which is still lacking

\section{REFERENCES}

1. https://dapo.dikdasmen.kemdikbud.go.id/pd.

2. Zuzy, A. (2020). Pencapaian Agenda Pendidikan Berkualitas Untuk Semua (SDG-4) Di Tengah
Disrupsi Pandemi Covid-19, SDGs Centre Universitas Padjadjaran, Publish on 5 June 2020.

3. Birkah, L., \& Kadarudin. (2013). Hukum Perjanjian Internasional, (Makassar: Pustaka Pena Press, 2013), p. 51

4. Birkah, L., \& Kadarudin. (2020). Pengantar Hukum Internasional, (Makassar: Pustaka Pena Press, 2013), p. 67 See also Kadarudin, Antologi Hukum Internasional Kontemporer, (Yogyakarta: Deepublish, 2020), p. 477.

5. Ministry of National Planning and Development of the Republic of Indonesia, Pendidikan Berkualitas, see http://sdgs.bappenas.go.id/tujuan4/

6. Masrufah Ihsan, Artikulasi SDGS 2030 dalam Pendidikan, Apa yang Perlu Dilakukan?, Kompasiana, publish on November 22, 2018.

7. The National Commission on Human Rights of the Republic of Indonesia, Kerangka Analisis untuk Mengintegrasikan Tujuan Pembangunan Berkelanjutan (SDGs) dengan Kewajiban Pemenuhan Hak-hak Asasi Manusia untuk di Indonesia, p. 1-2.

8. Soerjono, S., \& Sri Mamudji. (2011). Penelitian Hukum Normatif, (Jakarta: Rajawali Pers, 2011), p. 14.

9. Peter, M. M. (2010). Penelitian Hukum, (Jakarta: Kencana Prenada Media Group, 2010), p. 96.

10. Kadarudin. (2020). Mengenal Riset dalam Bidang Ilmu Hukum: Tipologi, Metodologi, dan Kerangka, (Ponorogo: Uwais Inspirasi Indonesia, 2020), p. 171.

11. Kadarudin. (2020). Isu-Isu Kejahatan Internasional \& HAM dalam Catatan Dr. Kadarudin, (Yogyakarta: Deepublish, 2020), p. 236.

12. Ministry of National Planning and Development of the Republic of Indonesia, Pendidikan Berkualitas, see http://sdgs.bappenas.go.id/tujuan4/

13. SDG 2030 Indonesia, see https://www.sdg2030indonesia.org/page/12tujuan-empat

14. The National Commission on Human Rights of the Republic of Indonesia, Loc.Cit., p. 3.

15. Masrufah, I. (2018). Artikulasi SDGS 2030 dalam Pendidikan, Apa yang Perlu Dilakukan?, Kompasiana, publish on November 22, 2018.

16. The National Commission on Human Rights of the Republic of Indonesia, Loc.Cit., p. 3-4.

17. Ibid. 